\title{
Final Technical Report \\ For the \\ Martin County \\ Hydrogen Fuel Cell Development Project
}

Submitted to

U.S. Department of Energy

Golden Field Office

Golden, CO

Cooperative Agreement No.

DE-FG36-08G088107

March 9, 2011

DOE Issue, Final

Prepared by Microcell Corporation 


\section{Table of Contents}

$\begin{array}{lll}1.0 & \text { GENERAL OVERVIEW } & 4\end{array}$

$\begin{array}{llc}2.0 & \text { TECHNOLOGY OVERVIEW } & 6\end{array}$

$\begin{array}{lll}3.0 & \text { PROJECT HISTORY } & 12\end{array}$

$\begin{array}{lll}3.1 & \text { BACKGROUND } & 12\end{array}$

$\begin{array}{lll}3.2 & \text { PROJECT SCOPE } & 12\end{array}$

3.3 DETAILED DESCRIPTION OF THE TASKS AND RESULTS 13

Task 1. Transfer of the Cell Extrusion from R\&D to manufacturing 13

Task 2. Increase production by doubling the speed of the extrusion process from 1 to $2 \mathrm{~m} / \mathrm{min}$.

Task 3. Scale up the Nafion preparation process. 15

Task 4. Improve the efficiency of the single cell fabrication process by enhancement of the cell wrapping process.

Task 5. Improve the electrical connections of Unicells in the fuel cell modules. 19

Task 6. Transfer module fabrication process from R\&D to the manufacturing facility. 19

Task 7. Simplify the fuel cell system design. $\quad 20$

$\begin{array}{lll}3.4 & \text { SUMMARY PROJECT SCHEDULE } & 22\end{array}$

4.0. KEY WORDS 


\section{Table of Figures}

FIGURE 1: EXTRUDED CELL

FIGURE 2: CELL CROSS SECTION

FIGURE 3: UNICELL

FIGURE 4: MULTI-UNICELL CASING

FIGURE 5: POLARIZATION CURVE OF A 12W UNICELL

FIGURE 6: FUEL CELL SYSTEM SPECIFICATIONS

FIGURE 7: PERFORMANCE COMPARISON

FIGURE 8: SINGLE EXTRUSION LINE CAPACITY

FIGURE 9: UNICELL PERFORMANCE WITH SCALED UP NAFION PREPARATION

FIGURE 10: WRAPPING EQUIPMENT

FIGURE 11A: WRAPPING EQUIPIMENT SETTINGS

FIGURE 11B: WRAPPING EQUIPIMENT SETTINGS

TABLE 1: FUEL CELL MODULE CHARACTERISTICS, MANUFACTURING VS. R\&D

TABLE 2: DESIGN REDUCTIONS AND CHANGES 
Martin County Hydrogen Fuel Cell Project

Final Technical Report

\subsection{GENERAL OVERVIEW}

Microcell was formed in 2000. In 2001, the Company secured a $\$ 2.0$ million grant from the National Institute for Standards and Technology (NIST) and an investment commitment from Potomac Electric Power Company (PEPCO) as the first investor owned electric utility joining Microcell. To date, the Company has added Progress Energy, Dominion Energy, American Electric Power, Duke Energy, and the North Carolina Electric Cooperatives to its list of investors and strategic partners. These electric utilities have made significant investment in Microcell's technology and have a long term interest in proliferation of this technology in their power distribution network.

The goal of this project was to transfer Microcell Corporation's microfiber fuel cell technology's manufacturing process from the research and development level to its manufacturing facility in Martin County, North Carolina and evaluate various parameters including production speed and product quality. This microfiber fuel cell technology has the ability to meet the need for high volume fuel cell manufacturing processes identified by the Department of Energy. With the sub-recipient's patented technology, single cell fuel cells are produced by a continuous extrusion process. As the speed of the extrusion line is increased, it is important that no bottlenecks occur in the subsequent processes. The outcome of this project is the acceleration of fuel cell technology and process development for mass production of cost-efficient fuel cells for commercial products.

According to the Fuel Cell Section of the Department of Energy Program's Multi-Year Research, Development, and Demonstration Plan, cost is one of the two most significant challenges facing fuel cell systems. This document also states that materials and manufacturing costs are too high for fuel cell components and that low-cost, highvolume manufacturing processes are necessary. In support of the Department of Energy's need to develop low-cost, high-volume manufacturing processes for fuel cells, this project has assisted in accelerating the research and development required for optimization and scale-up of an innovative manufacturing process with the capability for low-cost, mass production of microfiber-based PEM (polymer electrolyte membrane) fuel cells.

The main focus of the Martin County Hydrogen Fuel Cell Development Project is to advance the high volume manufacturing processes of a microfiber PEM fuel cell technology. This project impacts the Department of Energy's barriers to fuel cell commercialization as follows: 
- Movement toward high-performance catalysts enabling ultra-low precious metal loading (DOE Multi-Year Research, Development and Demonstration Plan, Technical Plan - Fuel Cells - Barriers, Section 3.4.B).

o Microcell's precious metal loading for Stationary Applications:

- $0.6-0.7 \mathrm{mg} / \mathrm{cm} 2$ Total Platinum loading - Current

- $<0.5 \mathrm{mg} / \mathrm{cm} 2$ Total Platinum loading - Near term

- $<0.3 \mathrm{mg} / \mathrm{cm} 2$ Total Platinum loading - Long term

- Movement toward low-cost, high-volume manufacturing processes (DOE MultiYear Research, Development and Demonstration Plan, Technical Plan - Fuel Cells - Barriers, Section 3.4.B).

o Microcell's high volume manufacturing line has the following characteristics:

- All components of single cell are extruded on line continuously

- Fully automated extrusion process

- Reduced material and component cost

- Each extrusion line capable of producing 1-3 MW of fuel cells per year

- Development of efficient heat recovery system for utilization of low-grade heat to achieve the most efficient systems for distributed power generation (DOE MultiYear Research, Development and Demonstration Plan, Technical Plan - Fuel Cells - Barriers, Section 3.4.E).

o Microcell's heat recovery system has the following characteristics:

- Combined Heat and Power efficiency of $>85 \%$

- $40 \%$ electrical, $45 \%$ thermal

- Net CHP efficiency of $>60 \%$

The purpose of this report is to provide a technical account of the total work performed for the project under the Cooperative Agreement between Martin County Economic Development Corporation and the U.S. Department of Energy. 


\subsection{TECHNOLOGY OVERVIEW}

Microcell Corporation has developed and commercialized a novel fuel cell based on a symmetric and microtubular "Microcell" architecture. Microcells are fabricated from nano-scale building blocks to form microtubular cells ranging in size from a few hundred microns to a few millimeters in diameter as shown in Figure 1.

\section{Figure 1: Extruded cell}

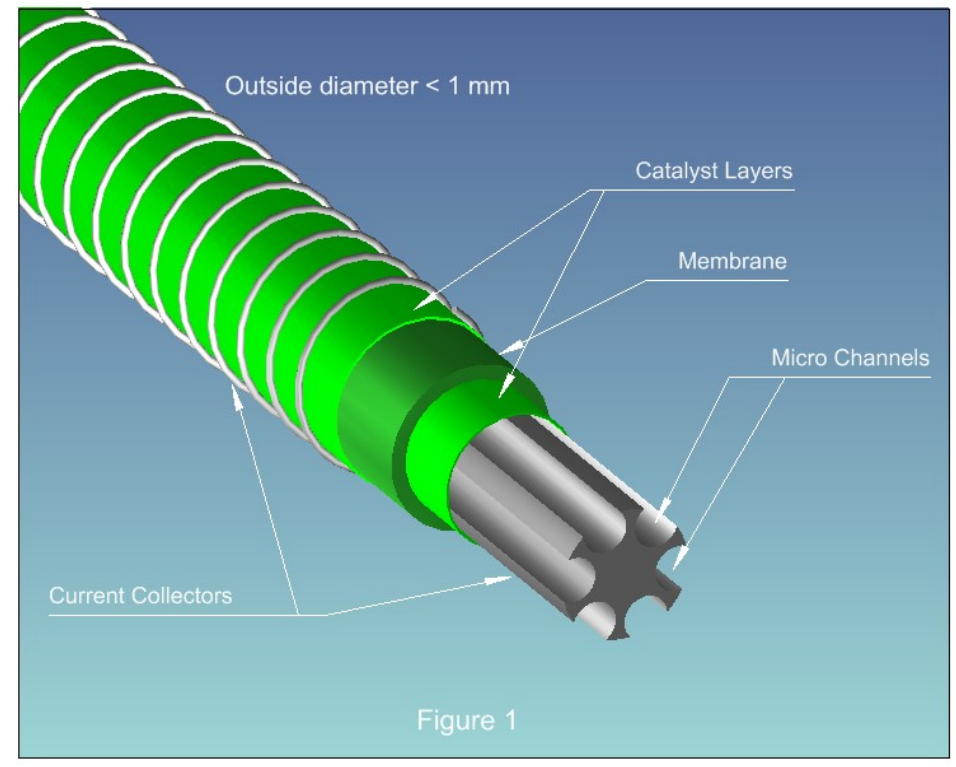

Each Microcell as shown above, with an OD of $\sim 900$ micron and a length of $\sim 15 \mathrm{~cm}$, produces $1 \mathrm{~W}-1.5 \mathrm{~W}$ of power. Microcell Corporation has advanced the technology over the past decade to the stage of high volume commercial production. At the center of this technology lies a low cost, highly corrosion-resistant metal alloy current collector with excellent electrical conductivity. The bore current collectors are grooved with micro channels to allow excellent contact between the catalyst layer and the entire surface of the current collector. A more detailed cross section of a Microcell structure is shown in Figure 2. Under a $\$ 2,000,000$ grant from NIST's Advanced Technology Program in 2001, Microcell Corporation developed the technology to mass produce these current collectors at costs needed to meet automotive applications. Microcell uses a polymer electrolyte membrane (Nafion), and platinum based catalysts currently used for conventional plate type PEM fuel cells. 


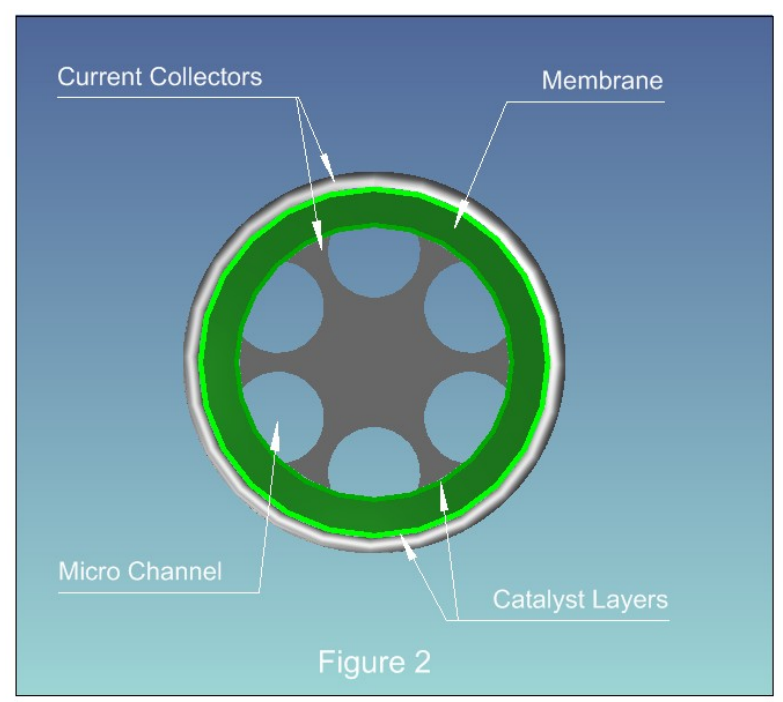

To increase the power level, cells are bundled and connected in parallel to produce a "Unicell" ranging in power from 10-15 W as shown in Figure 3.

Figure 3: Unicell

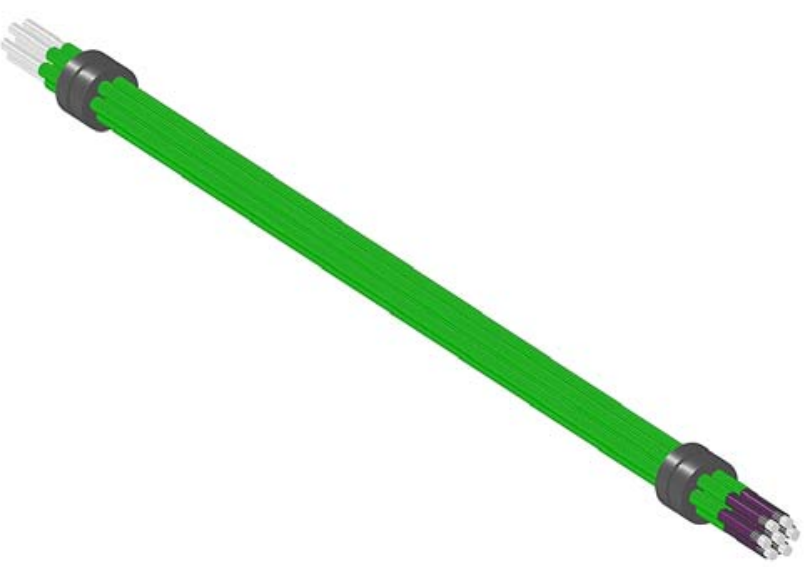


The Unicells are self-contained assemblies of the cells which are sealed at both ends to isolate the shell and bore side of the cells where air and fuel are supplied. Heat exchange tubes are placed at the center of the cell bundle in each Unicell for removal of the heat generated during the operation. The Unicells are then inserted inside a casing with built-in gas feeds, and the coolant circulation line. A simplified diagram of a multiUnicell casing is shown in Figure 4.

Figure 4: Multi-unicell casing

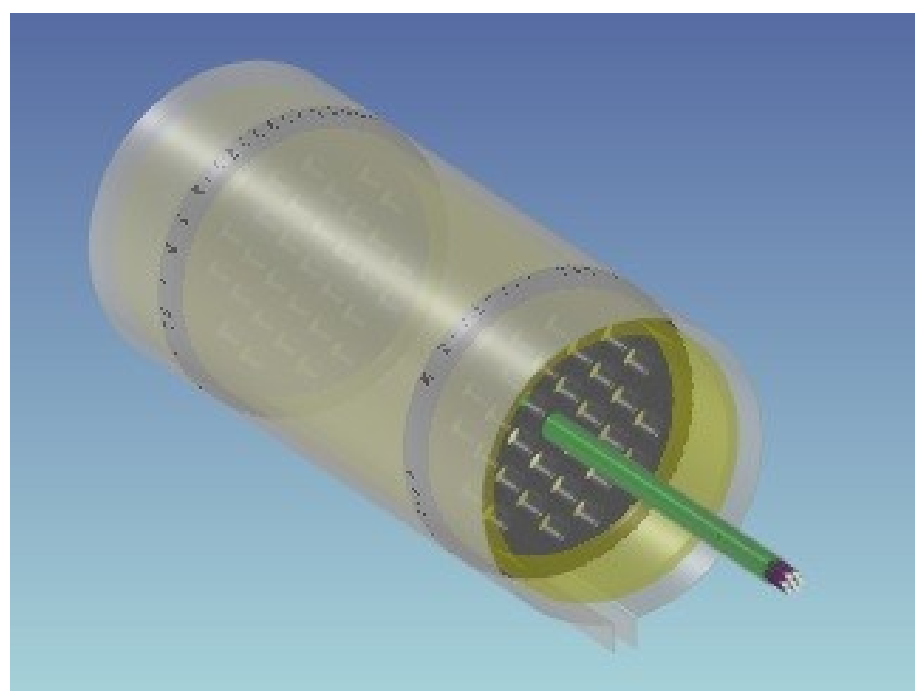

After insertion of the Unicells inside the casing, the electrical connections are made inside the end-caps at both ends, in series or parallel, depending on the voltage or current design requirement. The bulkheads on each end of the fuel cell module provide instant seal between the air and the fuel compartment as the Unicells slide and rest inside the bulkheads. Figure 4 depicts Microcell's current fuel cell design. 
Microcell has been producing pre-commercial and commercial $1 \mathrm{~kW}$ Micro-CHP fuel cell systems since 2007. Microcell's microtubular PEM fuel cell architecture offers several major benefits:

\section{1- Low cost extrusion based fabrication}

Microcells are produced by an extrusion process in which all components of the cell as shown in Figure 1 are continuously extruded at high outputs with minimal labor. This automated extrusion process is highly suitable for mass production of fuel cells by eliminating the labor cost for fabrication and assembly of very thin, high precision catalyst and membrane layers in the Membrane Electrode Assembly (MEA). Furthermore, because essentially raw materials are fed to the extrusion process, several components of the cell, such as the membrane, GDL, and catalyst sheets do not have to be purchased as a product produced by other manufacturers, minimizing the component costs. Figure 5 depicts the polarization diagram of single cell Unicell.

\section{Figure 5: Polarization curve of a 12W Unicell}

Fig. 5- Polarization Curve of a 12 W Unicell

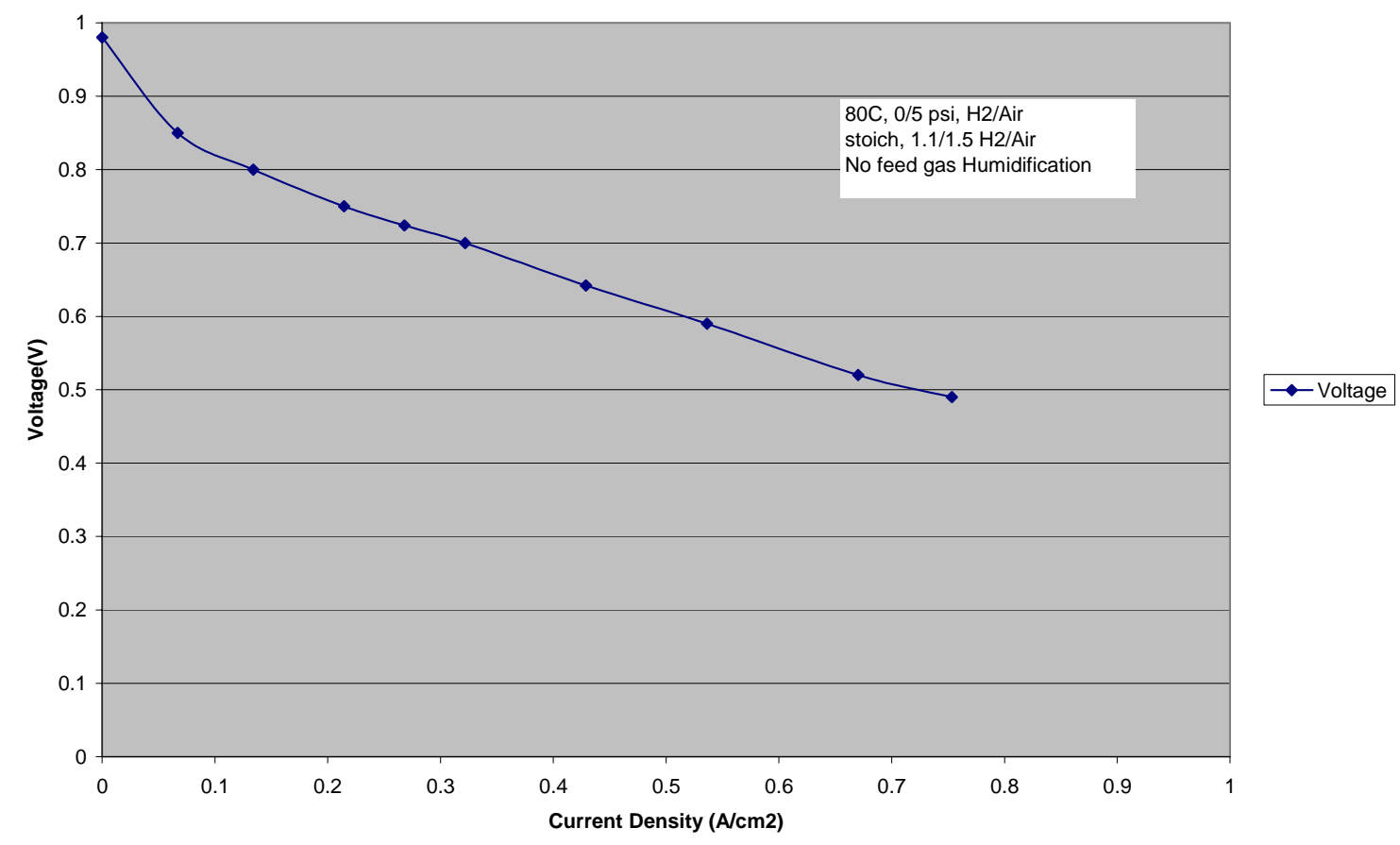




\section{2- Ease of Service and Repair}

Microcell's design allows for each individual Unicell to be removed and replaced without the requirement to disassemble the entire stack. In conventional fuel cell technology plates are essentially hard-wired in series and can not be easily separated and reassembled unless under the precision used at the manufacturing plant. The assembly of the plates is tedious work that requires expertise in order to achieve good results. Microcell Unicells are designed to be removed and replaced at the end user level.

\section{3- Advanced Thermal Management}

Microcell Unicells are packaged in a fashion that allows excellent surface contact between each and every cell and the heat exchange tube. This results in uniform and efficient heat removal from the cells and eliminates the formation of hot spots in the cell. Elimination of hot spots increases the service life of the fuel cell in distributed generation and automotive applications. This advanced heat removal system also enables very efficient recovery of heat for useful applications such as hot water heater and space heating applications even when operated on direct hydrogen with low temperature PEM fuel cells. Figure 6 is a specification sheet for Microcell's current products. 


\section{Figure 6: Fuel cell system specifications}

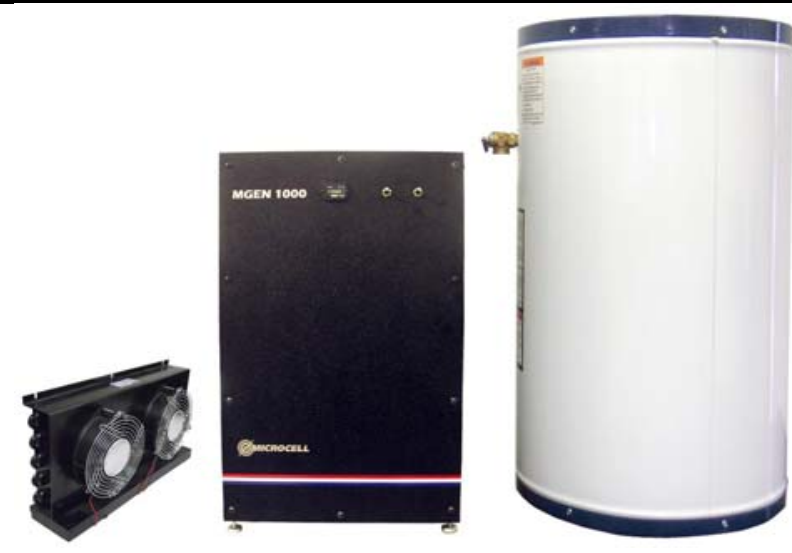

\begin{tabular}{|c|c|c|c|}
\hline PRODUCT CHARACTERISTICS & MGEN500 & MGEN1000 & MGEN3000 \\
\hline \multicolumn{4}{|l|}{ Fuel Cell Module } \\
\hline Type & PEM & PEM & PEM \\
\hline Power Output (Nominal) & $500 \mathrm{~W}$ & $1,000 \mathrm{~W}$ & $3,000 \mathrm{~W}$ \\
\hline Output Voltage & $48 \mathrm{Vdc}$ & $48 \mathrm{Vdc}$ & $48 \mathrm{Vdc}$ \\
\hline Output Voltage Regulation & $+1-5 \%$ & $+1-5 \%$ & $+1-5 \%$ \\
\hline Start Up Time & $<1 \mathrm{~min}$ to $50 \%$ load & $<1 \mathrm{~min}$ to $50 \%$ load & $<1 \mathrm{~min}$ to $50 \%$ load \\
\hline \multicolumn{4}{|l|}{ Optional Hot Water Heater } \\
\hline Size & 10 gallon & $30 / 40$ gallon & $40 / 50$ gallon \\
\hline Temperature & Adjustable, $140^{\circ} \mathrm{F}$ max & Adjustable, $140^{\circ} \mathrm{F} \max$ & Adjustable, $140^{\circ} \mathrm{F}$ max \\
\hline Time to Temperature & $1-2$ hours & $1-2$ hours & 1-2 hours \\
\hline \multicolumn{4}{|l|}{ Combined Heat and Power Efficiency } \\
\hline & $85 \% \mathrm{HHV}, \mathrm{Net}>60 \%$ & $85 \%$ HHV, Net $>60 \%$ & $85 \%$ HHV, Net $>60 \%$ \\
\hline \multicolumn{4}{|l|}{ Dimensions } \\
\hline Standard & $24 \times 21 \times 16$ inches & $27 \times 25 \times 17$ inches & $30 \times 30 \times 17$ inches \\
\hline Custom (not including fuel storage) & per specification & per specification & per specification \\
\hline \multicolumn{4}{|l|}{ Fuel Supply } \\
\hline Hydrogen & Industrial Grade & Industrial Grade & Industrial Grade \\
\hline \multirow{2}{*}{ Fuel Pressure } & $>40$ psi (supply) & $>40$ psi (supply) & $>40$ psi (supply) \\
\hline & 5-10 psi (on board) & 5-10 psi (on board) & 5-10 psi (on board) \\
\hline \multicolumn{4}{|l|}{ Operation } \\
\hline Warranty & $1 \mathrm{yr}$ & $1 \mathrm{yr}$ & $1 \mathrm{yr}$ \\
\hline Extended-Warranty (optional) & $5 \mathrm{yr}$ & $5 \mathrm{yr}$ & $5 \mathrm{yr}$ \\
\hline \multicolumn{4}{|l|}{ Emissions } \\
\hline Water & $<0.75$ liters/hour & $<1$ liter/hour & $<2.6$ liters/hour \\
\hline Noise & $<65 \mathrm{dBA}$ at 1 meter & $<65 \mathrm{dBA}$ at 1 meter & $<65 \mathrm{dBA}$ at 1 meter \\
\hline Heat (if not recovered) & $<4000 \mathrm{BTU} / \mathrm{hr}$ at peak power & $<7000 \mathrm{BTU} / \mathrm{hr}$ at peak power & $<19000$ BTU/hr at peak power \\
\hline \multicolumn{4}{|l|}{ Control } \\
\hline & $\begin{array}{l}\text { Microprocessor with LED } \\
\text { panel and alarms }\end{array}$ & $\begin{array}{l}\text { Microprocessor with LED } \\
\text { panel and alarms }\end{array}$ & $\begin{array}{l}\text { Microprocessor with LED } \\
\text { panel and alarms }\end{array}$ \\
\hline \multicolumn{4}{|l|}{ Monitoring } \\
\hline & $\begin{array}{l}\text { Local/Remote } \\
\text { Specifications subject to cha }\end{array}$ & $\begin{array}{l}\text { Local/Remote } \\
\text { ige without notice. }\end{array}$ & Local/Remote \\
\hline $\begin{array}{l}\text { Microcell Corporation } \\
\text { www.microcellcorp.com }\end{array}$ & $\begin{array}{l}\text { Headquarters } \\
6003 \text { Chapel Hill Road, Suite } 153 \\
\text { Raleigh, NC } 27607 \\
\text { Phone: } 919.858 .8500 \\
\text { Fax: } 919.858 .8615\end{array}$ & $\begin{array}{l}\text { Manufact } \\
8902 \text { High } \\
\text { Roberson } \\
\text { Phone: } 25 \\
\text { Fax: } 252 \text {. }\end{array}$ & $\begin{array}{l}\text { ast } \\
27871 \\
22\end{array}$ \\
\hline
\end{tabular}


Martin County Hydrogen Fuel Cell Project

Final Technical Report

\subsection{PROJECT HISTORY}

\section{$3.1 \quad$ BACKGROUND}

In September 2008, the U.S. Department of Energy and Martin County Economic Development Corporation entered into an agreement to further the advancement of a microtubular PEM fuel cell developed by Microcell Corporation. The overall focus of this project was on research and development related to high volume manufacturing of fuel cells and cost reduction in the fuel cell manufacturing process. The extrusion process used for the microfiber fuel cells in this project is inherently a low cost, high volume, high speed manufacturing process. In order to take advantage of the capabilities that the extrusion process provides, all subsequent manufacturing processes must be enhanced to meet the extrusion line's speed and output. Significant research and development was completed on these subsequent processes to ensure that power output and performance were not negatively impacted by the higher speeds, design changes and process improvements developed in this project. All tasks were successfully completed resulting in cost reductions, performance improvements and process enhancements in the areas of speed and quality. These results support the Department of Energy's goal of fuel cell commercialization. Continuing work on cost reduction and process improvements is underway.

\subsection{PROJECT SCOPE}

The goals and objectives of this project relate specifically to the manufacturing processes of a microfiber PEM fuel cell manufactured in Martin County, North Carolina by Microcell Corporation. This project began with the transfer of an extrusion process for microfiber PEM fuel cell production from research and development to the manufacturing floor. All equipment for this process was designed, constructed and installed at the manufacturing facility by Microcell engineers. The objective of this task was to move cell production to the manufacturing facility while maintaining similar cell properties and performance as those produced by research and development. This result was successfully accomplished and the manufacturing facility now produces all fuel cell microfibers for product assembly. After accomplishment of the main task of transferring the extrusion process to the manufacturing floor, several additional tasks were performed over a two year period to increase production, improve cell fabrication process, increase production efficiency, improve and simply fuel 
cell module and system design. Specifically, the tasks performed under this project were as follows:

Task 1: $\quad$ Transfer of the cell extrusion from research and development to manufacturing.

Task 2: $\quad$ Increase production by doubling the speed of the extrusion process from 1 to $2 \mathrm{~m} / \mathrm{min}$.

Task 3: $\quad$ Scale up the Nafion preparation process.

Task 4: Improve the efficiency of the single cell fabrication process by enhancement of the cell wrapping process.

Task 5: Improve the electrical connections of Unicells in the fuel cell modules.

Task 6: Transfer module fabrication process from R\&D to the manufacturing facility.

Task 7: $\quad$ Simplify the fuel cell system design.

\subsection{DETAILED DESCRIPTION OF THE TASKS AND RESULTS}

\section{Task 1. Transfer of the Cell Extrusion from R\&D to manufacturing}

The main and original goal of the project was to transfer the fuel cell extrusion process from the R\&D facility to the Martin County manufacturing facility in eastern North Carolina. Microcell has been working on development of this technology since 2000 and until this project, all of the cells were being produced at the R\&D facility employing highly skilled labor - many with advanced engineering degrees. The challenge was to produce the same cells in a manufacturing environment while maintaining the cell quality and performance. Microcell's extrusion process involves careful preparation of the catalyst and membrane composition, with proper and predetermined rheology, detailed set up of the extrusion dyes, monitoring and controlling process heaters, and other process equipment. These tasks must be performed in combination with a number of quality control steps to ensure precise control of the catalyst and membrane layer thicknesses and good quality cells. After 
extensive training of the manufacturing personnel at the R\&D facility this task was successfully completed in 2008 . Figure 7 shows the results of the cells produced with the extrusion runs performed at the manufacturing facility as compared to those of R\&D. Since 2008, Microcell has been producing all of the cells required for producing fuel cell modules for commercial applications at this manufacturing facility.

\section{Figure 7: Performance comparison}

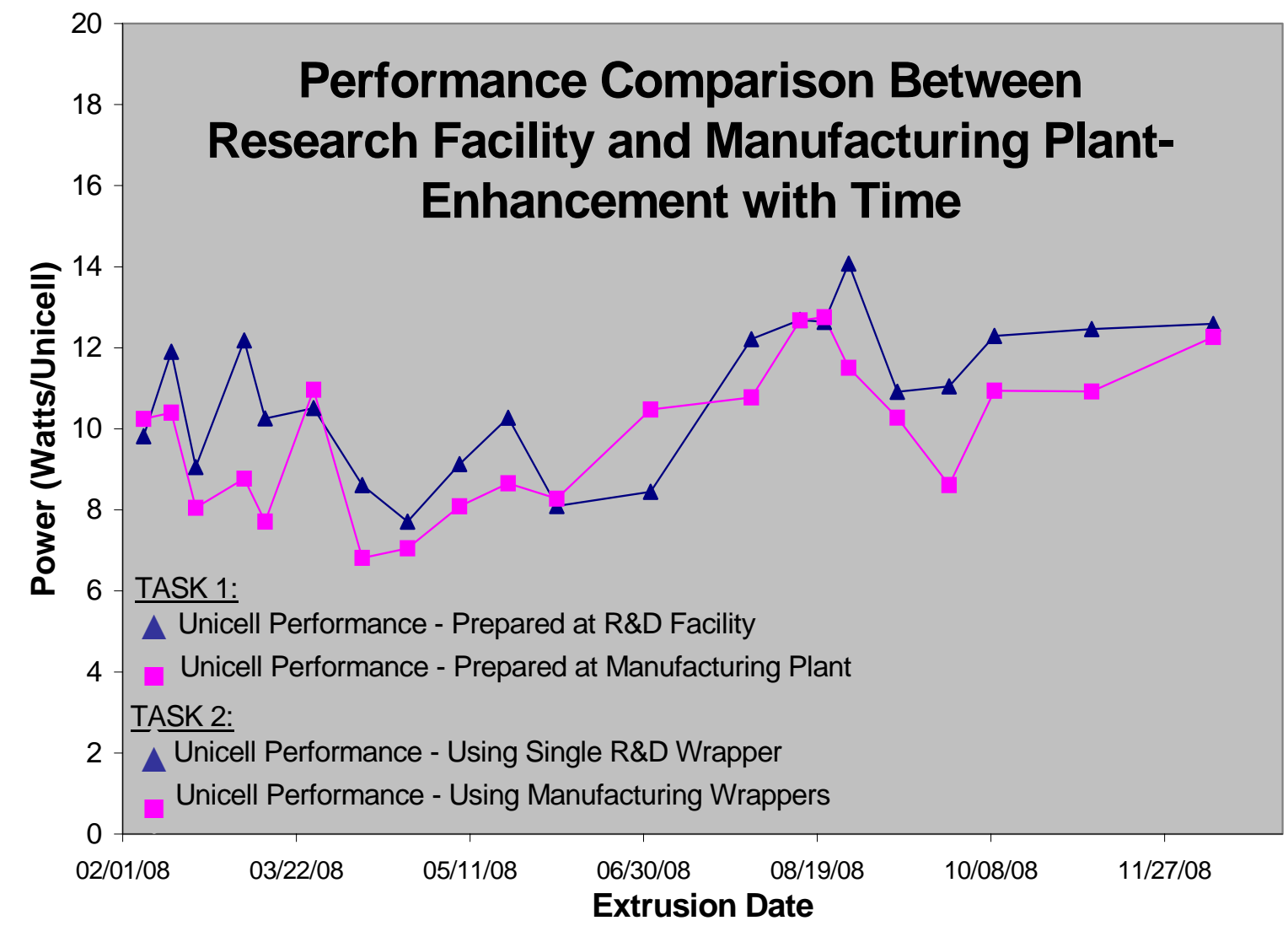

Task 2. Increase production by doubling the speed of the extrusion process from 1 to $2 \mathrm{~m} / \mathrm{min}$.

An advantage of employing an extrusion process is that fuel cell fabrication cost can be reduced by increasing the extrusion speed and subsequently the production rate. This step does not require any new capital investment and minimal labor increase while significantly increasing production. For example, 
in this task, Microcell demonstrated doubling the extrusion speed while this can be further improved by increasing the extrusion speed to 3 to 4 meters/min in the future. Microcell achieved this by addition of two process heating units and adjusting the process parameters to produce cells with similar quality and performance as those produced at $1 \mathrm{~m} / \mathrm{min}$.

Figure 8 below shows the effect in output of a single extrusion line through doubling the speed of the production line. No significant increase in labor or capital cost was required, resulting in reduced production cost per unit cell due to the increase in production capacity.

Figure 8: Single extrusion line capacity

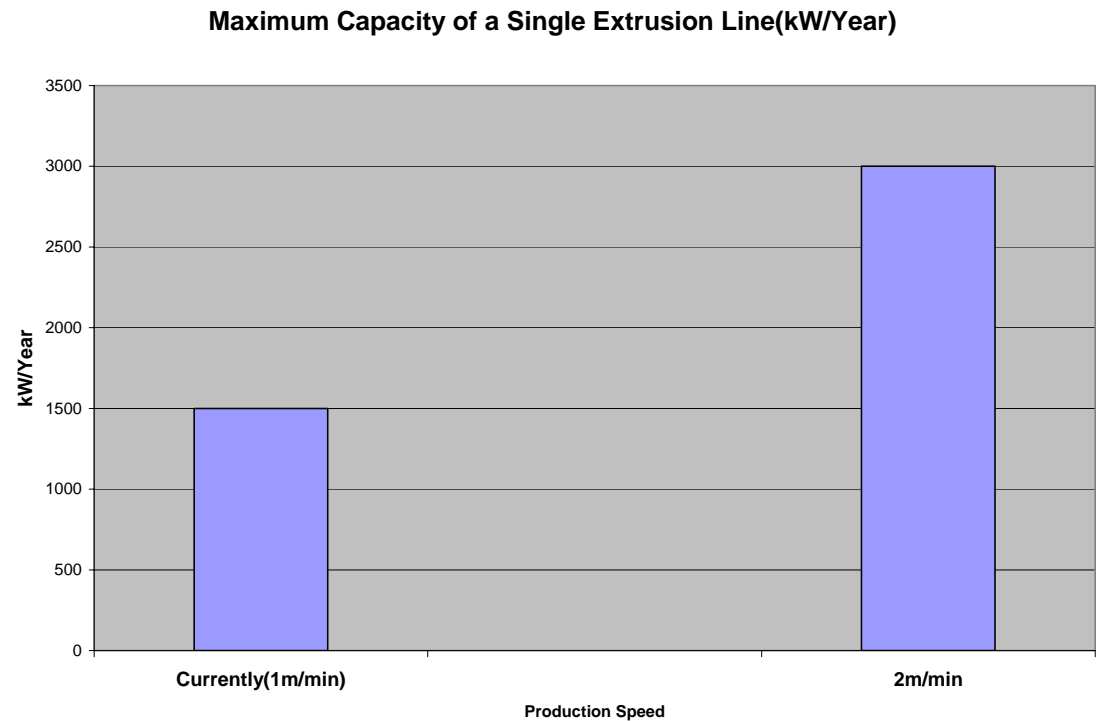

\section{Task 3. Scale up the Nafion preparation process.}

For manufacturing-scale production of the cells, large volume membrane raw material preparation and formulation is required. To achieve this, a membrane solution preparation apparatus had to be designed and constructed. After the construction and commissioning of the membrane material handling apparatus large batches of membrane solution were prepared and tested for quality and consistency. The objective of this task was to produce large volume membrane 
solutions with the requisite solids content and viscosity as required for the extrusion process. The goal was as shown in Figure 9 to produce Unicells with a performance target of $10-12 \mathrm{~W}$ to replicate the membrane properties of those prepared by the laboratory technique.

Figure 9: Unicell performance with scaled up Nafion preparation

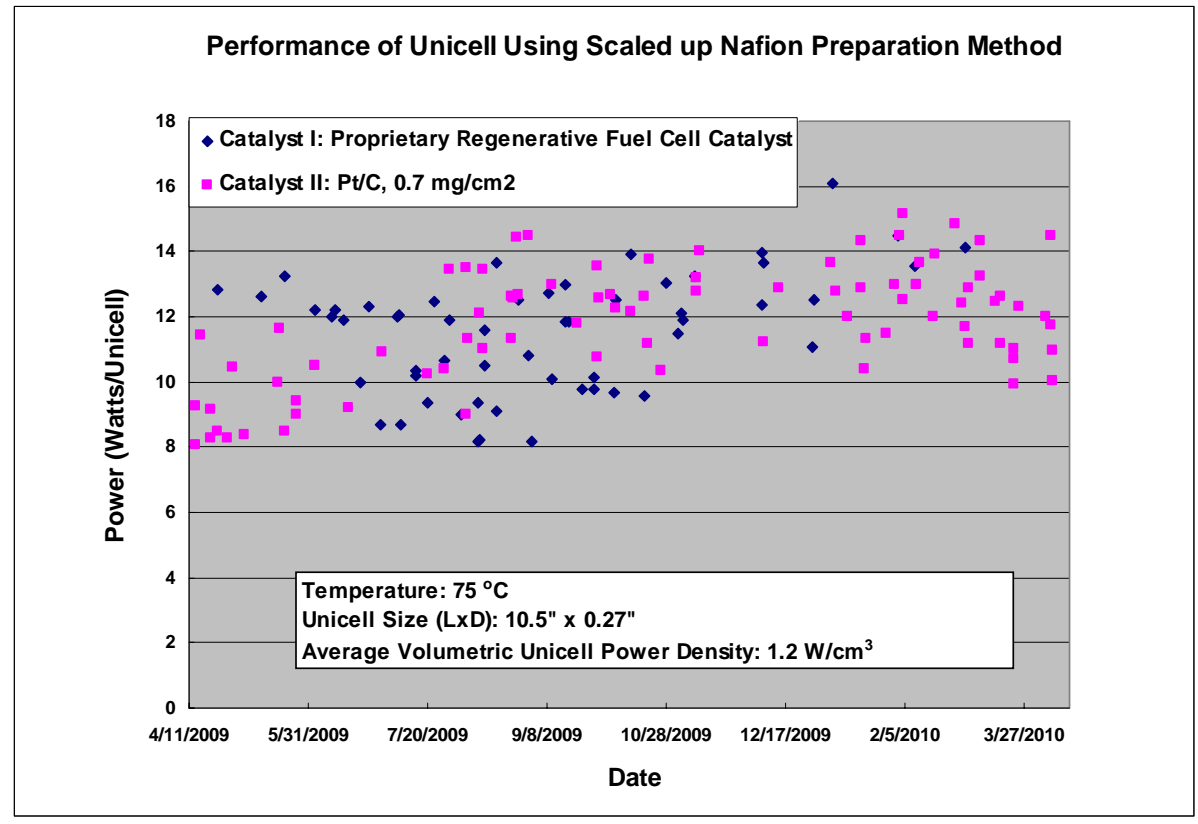

Task 4. Improve the efficiency of the single cell fabrication process by enhancement of the cell wrapping process.

Unicell production processes include a wire wrapping technology for the bundling of the fuel cell fibers (Figure 10). This process requires quick modification and adjustments by the equipment operator. In this task, the Unicell process equipment was to be evaluated to determine how to fine tune the process parameters in order to increase and optimize the Unicell throughput.

To achieve this, the manual adjustments, as had been the case with the original equipment, were fully automated by interfacing the cell wrapping process with a laptop computer. A software program was developed in-house and integrated into the 
wrapping machine with a microprocessor that controlled the wrapping parameters. Figures $11 \mathrm{a}$ and $11 \mathrm{~b}$ show examples of the screen shots of the program that enabled the operators to make instant changes to the process where previously it required hours of disassembly and re-assembly. This change resulted in improving the efficiency and quality of the cell fabrication process by enabling the operator to make quick adjustments to the machine parameters if the wrapping function was not producing the desired results.

\section{Figure 10: Wrapping equipment}

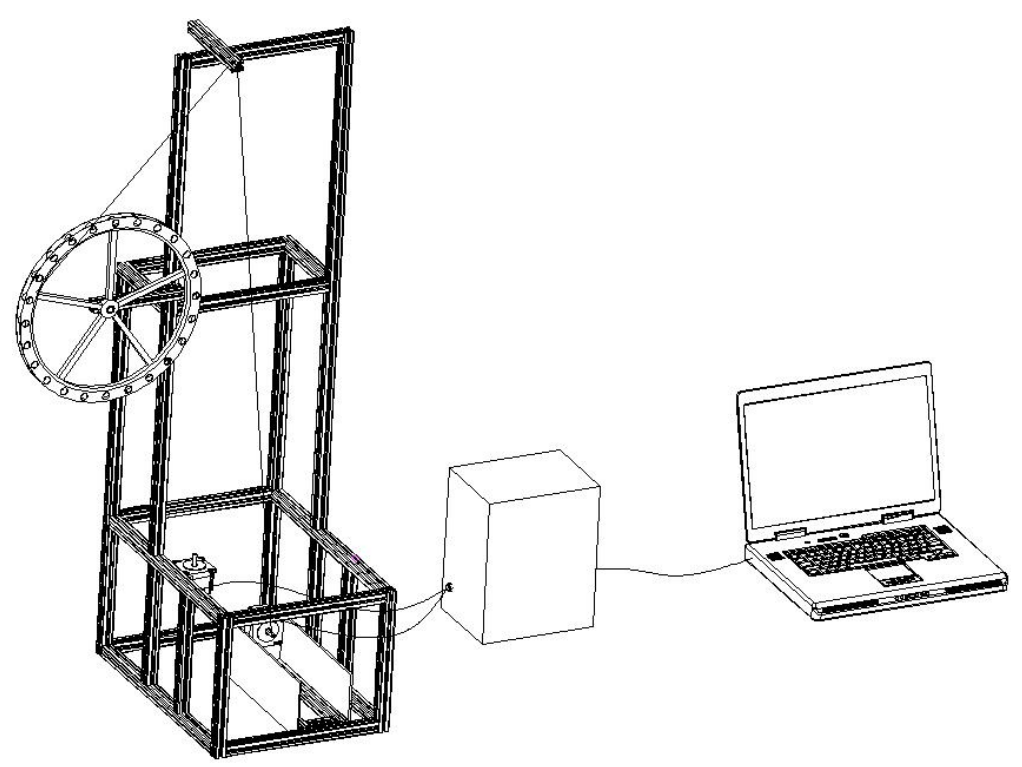


Figure 11a: Wrapping equipiment settings

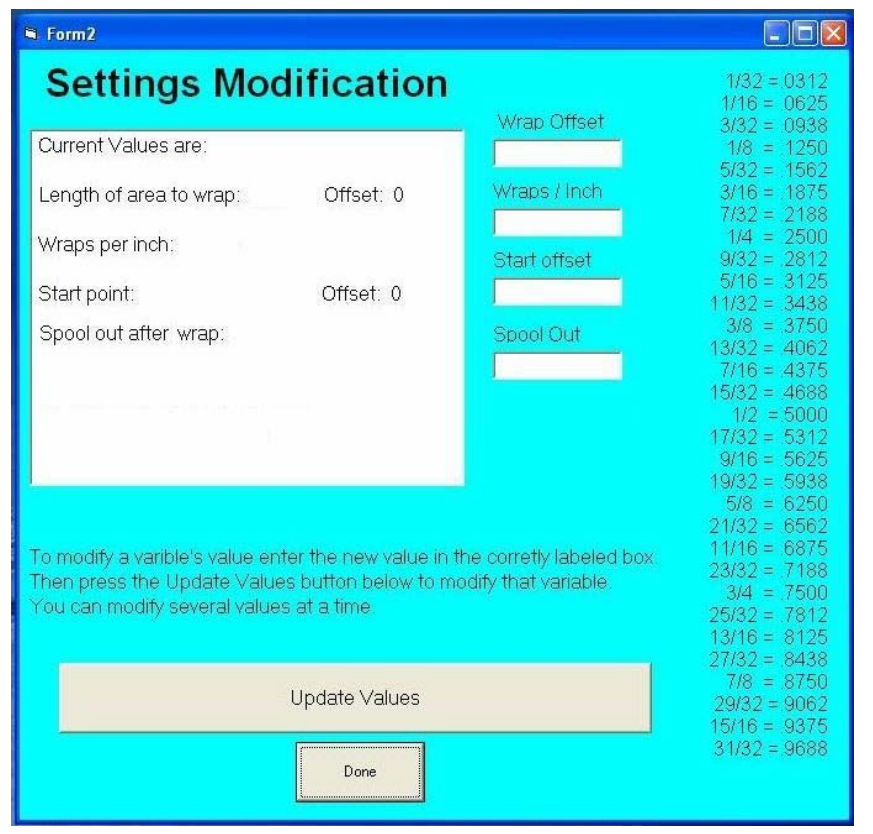

\section{Figure 11b: Wrapping equipiment settings}

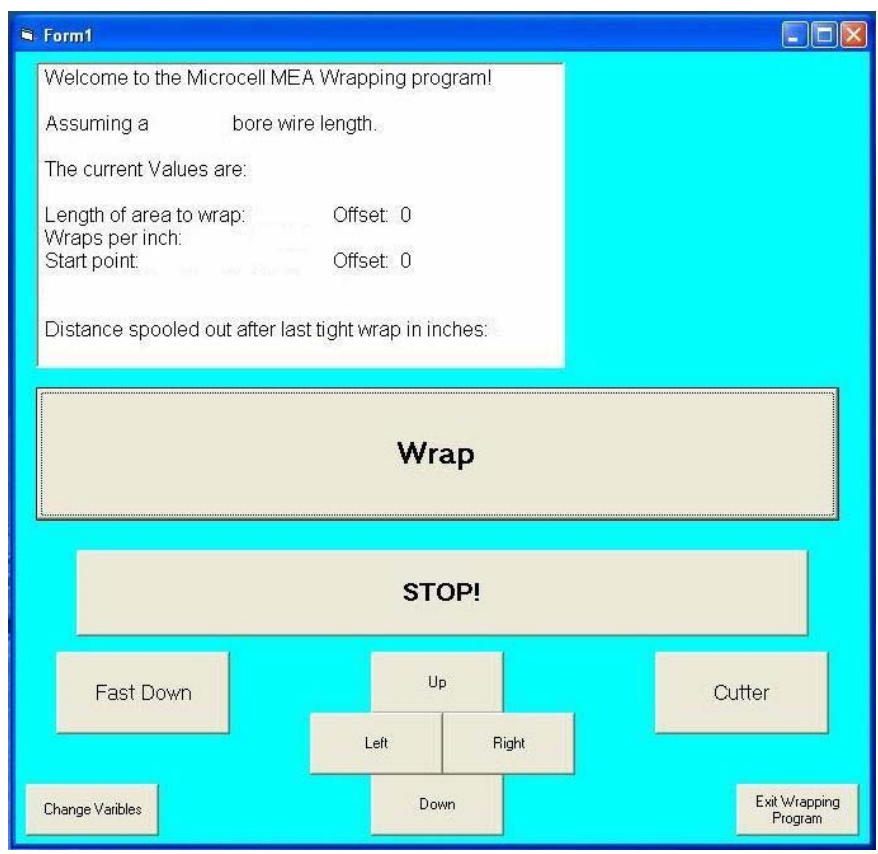


Task 5. Improve the electrical connections of Unicells in the fuel cell modules.

During the fuel cell module fabrication, once the Unicells are inserted into the fuel cell module, electrical connections are made at the end of the module. For example, a fuel cell module may contain 60 Unicells. To electrically connect these sixty cells with three cells in parallel, 20 connectors are required at each end of the module to complete the electrical connection of each Unicell in the module. These connectors which are placed at the end cap of the module as shown in Figure 4 must stay electrically separated for the life of the fuel cell. Otherwise, movement and excessive vibrations could bring the connectors close enough to cause soft shorts which will lower the performance of the units. A redesign and simplification of these electrical connections was needed to prevent short circuiting and allow for simplified scale up of the module assembly process in a manufacturing environment. To achieve this, the size of the electrical connectors was reduced and, once attached to the Unicells, electrically insulated from each other to prevent short circuiting during the life of the fuel cells.

The changes made to the electrical design significantly improved reliability of the fuel cell performance and power level.

\section{Task 6. Transfer module fabrication process from R\&D to the manufacturing facility.}

After the redesign of the electrical connections and module assembly, the next task was to move the construction of the fuel cell modules from research and development to the manufacturing floor. To allow for a smooth transition, new employees were hired for module production and trained at the R\&D facility for 30 days prior to returning the manufacturing plant. A test rig for leak checking of the fuel cell modules was fabricated and installed. Module production was successfully transferred to the manufacturing facility and since then all modules for Microcell fuel cell systems are now produced in Martin County. The performance characteristics of modules produced by research and development as compared to those produced at the production facility is shown in Table 1. 
Table 1: Fuel Cell Module Characteristics, Manufacturing vs. R\&D

Fuel Cell Module Characteristics

\begin{tabular}{|l|c|c|}
\cline { 2 - 3 } \multicolumn{1}{c|}{} & Production & R\&D \\
\cline { 2 - 3 } \multicolumn{1}{c|}{} & & \\
\cline { 2 - 3 } \multicolumn{1}{c|}{ Operating Temperature } & $65-70 \mathrm{C}$ & $65-70 \mathrm{C}$ \\
\hline & & \\
\hline Module Size (inches) & 3 "OD $\times 12 " \mathrm{~L}$ & 3 3"OD x12"L \\
\hline & & 12 \\
\hline Voltage & 12 & \\
\hline & & 0.6 \\
\hline Single Cell Voltage & 0.6 & \\
\hline & & 45 \\
\hline Current(A) & 44.2 & \\
\hline & & 540 \\
\hline Power (W) & 530 & \\
\hline & & \multicolumn{1}{|c|}{} \\
\hline
\end{tabular}

\section{Task 7. Simplify the fuel cell system design.}

The final step in the fuel cell production process is system assembly. By evaluating the design and components of the system, it was anticipated that simplification of the system could be achieved resulting in increased assembly speed and reduced system cost. The outcome of the evaluation identified a number of design changes including elimination of the electronic temperature controller, valves and excessive humidification equipment. Microcell engineers identified and implemented the reductions and changes shown in Table 2. 
Table 2: Design reductions and changes

\begin{tabular}{|l|l|}
\hline Original Design & Modified Design \\
\hline $\begin{array}{l}\text { Electronically controlled coolant } \\
\text { temperature controller }\end{array}$ & Eliminated \\
\hline $\begin{array}{l}\text { Valves and air flow controls for } \\
\text { humidification }\end{array}$ & Eliminated \\
\hline $\begin{array}{l}\text { Fuel cell module, balance of plant, } \\
\text { power electronics }\end{array}$ & $\begin{array}{l}\text { Compartmentalized to allow for easy } \\
\text { access, identified lower cost pumps } \\
\text { and accessories }\end{array}$ \\
\hline
\end{tabular}

In addition to the elimination of some of the balance of plant components, the fuel cell system was redesigned to separate the fuel cell hardware such as, pumps, valves, reservoir, etc., from the electronic components. With this redesign, all of the electronic components were placed in a separate retractable compartment for easy access and future maintenance. 


\subsection{SUMMARY PROJECT SCHEDULE AS DISCLOSED IN DOE QUARTERLY REPORTS}

The summary project schedule below illustrates the major project activities for the Martin County Hydrogen Fuel Cell.

FY2008 Project

Task 1 Milestone: The goal of this task is to show that extrusion line production can be reliably duplicated at a manufacturing level. This will be shown by comparing the power output of cells produced in the research \& development facility and those produced on the manufacturing line. The performance targets are shown below.

Actual completion date: August 31, 2008

Percent complete: $100 \%$

Task 2 Milestone: Show that increased throughput of Unicell production equipment (pieces/time) after enhancement and optimization can be achieved while maintaining consistent Unicell performance (power output).

Actual completion date: September 30, 2008

Percent complete: $100 \%$

Task 3 Milestone: Show that reducing balance of plant components and simplifying operating procedures can be accomplished with only minimal impact on module output power.

Actual completion date: December 31, 2008

Percent complete: $100 \%$

FY2009 Project (FY08 Project Continuation)

Task 1 Milestone: Compare the output of cells produced on the manufacturing line at 1 meter/minute and 2 meters/minute to verify that extrusion line production speed can be reliably increased at the manufacturing level with a negligible decrease in performance.

Actual completion date: August 2010

Percent complete: $100 \%$ 
Task 2 Milestone: Verify that the power output of cells produced with and without the new membrane production process is equivalent.

Actual completion date: December 2009

Percent complete: $100 \%$

Task 3 Milestone: Show that changes to the electrical connections result in the ability to increase the reliability of the fuel cell modules.

Actual completion date: August 2010

Percent complete: $100 \%$

Task 4 Milestone: Compare the Unicell throughput and power output of low volume production equipment against the Unicell throughput and power output using high volume production equipment by enhancement modifications to the wrapping machines. Increase efficiency and productivity.

Actual completion date: August 2010

Percent complete: $100 \%$

Task 5 Milestone: Show that fuel cell modules produced at the manufacturing facility will meet the same performance targets as those produced at the R\&D facility.

Actual completion date: August 2010

Percent complete: $100 \%$

\subsection{KEY WORDS}

Fuel cell, microfiber, extrusion, hydrogen, manufacturing, cost reduction, high volume production, high speed production, production efficiency 